\title{
LAGU SEBAGAI MEDIA PEMBELAJARAN BAHASA ARAB
}

\author{
Nurhapsari Pradnya Paramitha \\ Sekolah Tinggi Agama Islam Masjid Syuhada Yogyakarta \\ Jannah_484@yahoo.com
}

\section{Abstrak}

Kekuatan dahsyat lagu yang dianggap biasa dapat sengaja digunakan untuk berbagai macam tujuan. Lagu dapat dijadikan sebagai motivator atau hadiah atas terselesaikannya tugas dan tanggung jawab. Lagu bisa menjadi sangat efektif di bidang akademis, dengan membantu pembentukan pola belajar, mengatasi kebosanan, dan menangkal kebisingan internal yang menggganggu (atau percakapan dalam pikiran). Lagu juga dapat membantu mengatur waktu dengan menciptakan kecepatan yang diinginkan. Dengan menstimulasi pikiran, mengaktifkan emosi, serta menyingkirkan keheningan yang kaku, musik mendorong terjadinya percakapan sosial, membantu dan mengembangkan hubungan antar pribadi. Bahkan aktivitas mendengarkan musik saja telah terbukti mampu meningkatkan keterampilan mendengar secara umum, meningkatkan perhatian, dan mengungkapkan pandangan serta perasaan. Penggunaan lagu dalam pembelajaran Bahasa Arab dapat menigkatkan daya ingat dan memahami mufrodat/kalimah secara efektif, selain itu menyanyikan lagu berbahasaArab dapat membantu mengembangkan kalam dengan intonasi yang alami. Karena pada dasarnya pemerolehan bahasa dimulai melalui pendengaran (istima').

Keyword : lagu, PembelajaranBahasa Arab

\section{Abstrack}

The tremendous power of a song that is considered ordinary can be deliberately used for various purposes. Songs can be used as a motivator or reward for the completion of tasks and responsibilities. 
Songs can be very effective in academics, by helping the formation of learning patterns, coping with boredom, and counteracting intrusive internal noise (or conversations in the mind). Songs can also help manage time by creating the desired speed. By stimulating the mind, activating emotions, and eliminating rigid silence, music encourages social conversation, helps and develops interpersonal relationships. Even music listening activities alone have been shown to improve general listening skills, increase attention, and express views and feelings. The use of songs in Arabic learning can improve memory and understand mufrodat/sentence effectively, besides singing Arabic songs can help develop speaking with natural intonation. Because basically language acquisition starts by listening (istima').

Keyword: song, Arabic learning

\section{A. Pendahuluan}

Ahli pendidikan memandang pentingnya melibatkan multi indra, emosi dan kognisi siswa dalam kegiatan pembelajaran. Semakin tinggi pelibatan multi Indera, akan semakin besar tingkat belajar siswa. Demikian pula semakin banyak emosi dan kognisi terlibat dalam proses pembelajaran semakin banyak pemahaman yang diperoleh. Bagan berikut menunjukkan tingkat partisipasi indera dalam kegiatan pembelajaran.

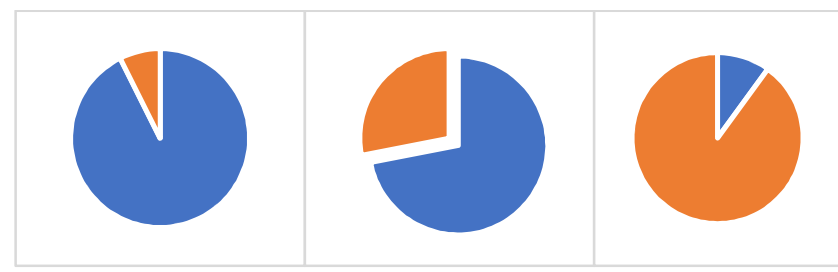

112 Jurnal Komunikasi dan Pendidikan Islam, Volume 1, Nomor 1, Juni 2018 
Nurhapsari Pradnya Paramitha : Lagu sebagai Media Pembelajaran Bahasa Arab
A
B
C

Keterangan :

A. Menyimak $15 \%$

B. Mendengar dan melihat 25\% - 55\%

C. Mendengar, melihat, berfikir dan mencoba $80 \%-90 \%$

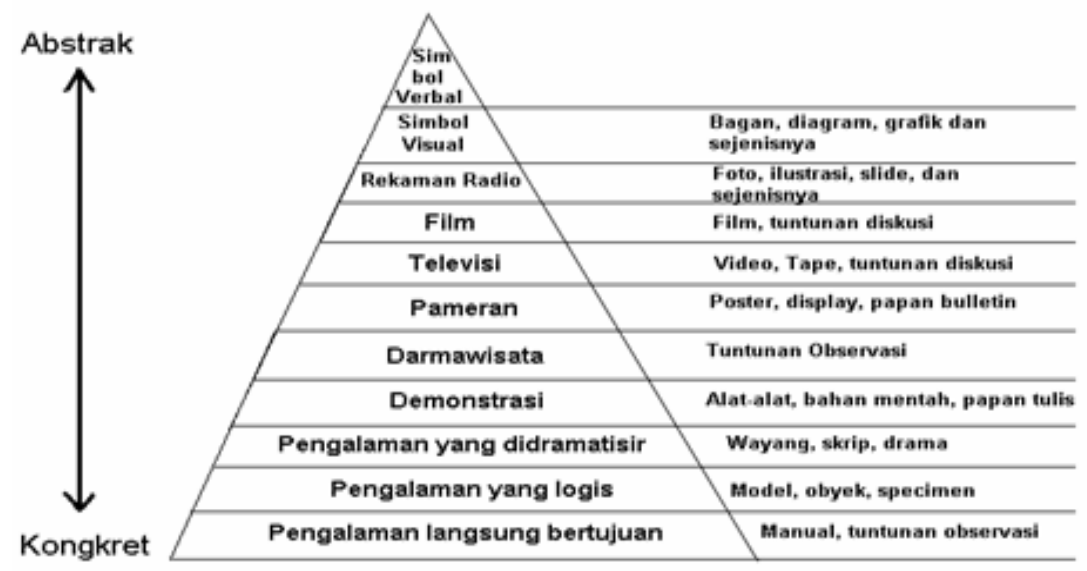

Edgar Dale menggambarkan tingkat penyerapan informasi melalui berbagai pengalaman dalam bentuk kerucut. Kadar pemahaman akan semakin besar jika dimunculkan stimulus yang lain, misalnya stimulus pandang, gerak bahkan sampai pelibatan siswa untuk mendapatkan pengalaman baik pengalaman buatan maupun pengalaman nyata. Luas sempitnya lebar kerucut menggambarkan luas sempitnya pemahaman yang diperoleh siswa.

Urgensi media dalam pembelajaran Bahasa Arab diperlukan diantaranya untuk: (1) membatasi/ mengurangi penggunaan tehnik terjemah, (2) memastikan bahwa siswa benar-benar memahami makna, (3) menambah kemenarikan 
dan kesenangan siswa terhadap pelajaran dan (4) menjadi stimulus atau perangsang peran serta keterlibatan siswa.

Medialagu merupakansaranatepatyang bias dimanfaatkandalam pembelajaran bahasa Arab.Melaluilagu,siswaakanterbawasuasanahatinyakedalamal unankata- kata.Aizid menyatakanbahwalagu ataumusicdapatmeningkatkanintelegensikarena rangsangan ritmis mampu meningkatkan fungsi kerja otak manusia, seperti membuatsaraf-sarafotak

bekerjasertamenciptakanrasanyamandantenang sehingga fungsi kerjaotakmenjadi optimal. Rangsangan ritmisdarilaguyang diperdengarkan itulah yangdapat meningkatkan kemampuan berbahasa, kreativitas,konsentrasi,dandayaingat.

\section{B. Pembahasan}

Pembelajaran bahasa Arab sebagai salah satu bahasa asing melibatkan komponen kebahasaan dan komponen pembelajaran. Komponen kebahasaan diantaranya tata bunyi; keterampilan berbahasa, seperti berbicara (kalam), menulis (kitabah), membaca (qiro'ah), mendengar (istima'); dan tatabahasa. Komponen pembelajaran diantaranya rencana pembelajaran, tujuan pembelajaran, strategi, metode, media, sumber belajar dan teknik evaluasi pembelajaran. Kedua 
komponen tersebut merupakan komponen penting yang tidak dapat dihilngka salahsatunya.

Keberadaan Media pembelajaran sebagai salah satu komponen pembelajaran sangat penting. Salahsatunya untuk mempercepat dan mempermudah penyerapan informasi oleh pembelajar. Sehingga pembelajar tidak merasa jenuh dalam belajar. Demikian pula dalam pembelajaran bahasa Arab, dimana peserta didik disuguhi bahasa asimg yang jarang mereka gunakan. Penggunaan metode drilling dilakukan untuk menanaman pengetahuan dan pemahaman siswa dapat memunculkan kejenuhan elajar

Kemajuan ilmu pengetahuan dan teknologi mendorong upaya-upaya pembaharuan memanfaatkan hasil teknologi dalam proses belajar mengajar. Para guru dituntut mampu menggunakan media media baru dan tidak menutup kemungkinan alat-alat tersebut sesuai dengan perkembangan dan tuntutan zaman. Minimal, Guru dapat menggunakan media sederhana dalam upaya mencapai tujuan pengajaran yang diharapkan. Selain menggunakan media atau alat yang sudah ada, diharapkan guru mampu mengembangkan media pembelajaran.

Kata "media" berasal dari bahasa latin dan merupakan bentuk jama' dari kata medium yang secara terminologi berarti 
perantara atau pengantar. ${ }^{63}$ Menurut bahasa Arab, media berasal dari kata wasaaila artinya perantara atau pengantar pesan dari pengirim ke penerima pesan. $^{64}$ Suparno mengemukakan bahwa media pembelajaran adalah segala yang digunakan sebagai saluran untuk menyampaikan pesan atau informasi dari satu sumber kepada penerima pesan. ${ }^{65}$ Pesan dapat disampaikan melalui audio, visual maupun audio visual.

Muncul pertanyaan lebih lanjut "apakah media pembelajaran sama dengan alat bantu pembelajaran?" sejalan dengan definisi di atas bahwa media pelajaaran merupakan alat yang digunakan agar kegiatan pembelajaran lebih mudah, cepat dan ringan maka media pelajaran juga mencakup alat bantu pembelajaran. Sehingga dapat dikatakan bahwa media pembelajaran lebih luas daripada alat bantu pembelajaran.

Sejarah penggunaan media pembelajaran sebenarnya sudah dimulai sejak Allah menciptakan manusia pertama kali. Untuk membuktikan kebesaran Allah, Allah mengajarkan nama-nama benda kepada Adam. Selanjutnya allah menggambarkan buah khuldi sebaagai penyebab kesesatan manusia. Pada masa putra Adam, Allah mengutus burung gagak mengajarkan cara menguburkan kawannya yang mati

63 Arif S. sardiman, Media pendidikan : pengertian, pengembangan, dan pemanfaatannya, (Jakarta: Rajawali, 1990), hal.6

64 Abdul Hamid, dkk, Pembelajaran Bahasa Arab: Metode, Strategi< Materi dan Media, (Malang:UIN Malang Press, 2010) hal.168

65 Imam Asrori, hal. 3-4 
dengan mematuk-matuk tanah agar terbentuk lubang sehingga Qabil meniru burung gagak untuk menguburkan jenazah Habil.

Rasulullah pun seringkali menggunakan media pembelajaran dalam menyampaikan pesannya. Sebagaimana saatia menggambarkan dirinya dengan penyantun anak yatim. Beliau mengibaratkan dirinya dan penyantun anak yatim dengan dua jarinya (telunjuk dan jari tengah) yang saling berhimpitan. Dengan maksud penyantun anak yatim akan berada sangat dekat dengan rasulullah di surga nanti.

Nampak jelas bahwa media pembelajaran merupakan komponen penting yang tak dapat dipisahkan dari kegiatan belajar mengajar. Media pembelajaran juga berlaku bagi segala usia. Baik untuk anak usia dini maupun bagi orangtua. Manfaat praktis media pembelajaran di dalam proses belajar mengajar sebagai berikut :

1. Media pembelajaran dapat memperjelas penyajian pesan dan informasi sehingga dapat memperlancar dan meningkatkan proses dan hasil belajar.

2. Media pembelajaran dapat meningkatkan dan mengarahkan perhatian anak sehingga dapat menimbulkan motivasi belajar, interaksi yang lebih langsung antara siswa dan lingkungannya, dan kemungkinan siswa untuk belajar sendiri-sendiri sesuai dengan kemampuan dan minatnya. 
3. Media pembelajaran dapat mengatasi keterbatasan indera, ruang dan waktu

4. Media pembelajaran dapat memberikan kesamaan pengalaman kepada siswa tentang peristiwa-peristiwa di lingkungan mereka, serta memungkinkan terjadinya interaksi langsung dengan guru, masyarakat, dan lingkungannya misalnya melalui karya wisata. ${ }^{66}$

Media pembelajaran memiliki fungsi yang beragam diantaranya :

1. Fungsi Media Pembelajaran Sebagai Sumber Belajar Secara teknis

Media belajar sebagai Sumber belajar merupakan fungsi utama media. Sebagai sumber belajar media pembelajaran dapat menggantikan fungsi guru terutma sebagai sumber belajar. Mudhoffir menyebutkan bahwa sumber belajar pada hakekatnya merupakan komponen sistem instruksional yang meliputi pesan, orang, bahan, alat, tehknik dan lingkungan,diman alat tersebut dapat mempengaruhi hasil belajar siswa. Dengan demikian sumber belajar dapat di pahami sebagai segala macam sumber dari luar diri seseorang yang dapat memudahkan peroses belajar.

2. Fungsi Semantik

66 Azhzar Arsyad, Media Pembelajaran( jakarta; Raja Grafindo, 2007), hal. 27 
Nurhapsari Pradnya Paramitha : Lagu sebagai Media Pembelajaran Bahasa Arab

Fungsi semantik merupakan kemampuan media dalam menambah perbendaharaan kata dengan makna atau benar-benar di pahami oleh anak didik. 


\section{Fungsi Manipulatif}

Fungsi manipulatif ini didasarkan pada ciri ciri umum yang sebagai mana tersebut $\mathrm{di}$ atas. Berdasarkan karakteristik umum ini, media memiliki dua kemampuan, yakni mengatasi batas ruang dan waktu dan mengatasi keterbatasan indrawi.

4. Fungsi Psikologis

Secara psikologis, media pembelajaran memiliki funsi atensi dengan maksud media pembelajaran dapat meningkatkan perhatian (attention) siswa terhadap materi ajar. Setiap orang memiliki sel saraf penghambat, yakni sel khusus yang berfungsi membuang sejumlah sensasi yang datang. Dengan adanya sel penghambat ini para siswa dapat memfokuskan perhatiannya pada rangsangan yang di anggapnya menarik dan membuan rangsangan yang lainnya. Dengan demikian, media belajar yang tepat guna adalah media belajar yang menarik dan memfokuskan siswa.

Sedangkan Sudrajat (2007) mengemukakan fungsi media menjadi delapan bagian diantaranya :

1. Media Pembelajaran dapat mengatasi pengalaman yang dimiliki oleh siswa. Apabila siswa tidak dapat dibawa langsung ke objek yang dipelajari, maka objeklah yang dibawa ke siswa 
2. Media Pembelajaran dapat melampaui batas ruang dan kelas

3. Media pembelajaran dapat memungkinkan adanya interaksi langsung antara siswa dengan lingkungan

4. Media pembelajaran menghasilkan keragaman pengamatan

5. Media pembelajaran dapat menanamkan konsep dasar yang benar, konkrit, dan realistis

6. Media pembelajaran membangkitkan keinginan dan minat baru siswa

7. Media pembelajaran memotivasi dan merangsang siswa belajar

8. Media pembelajaran memberikan pengalaman yang integral/ menyeluruh dari konkrit sampai abstrak.

Berdasarkan fungsi-fungsi diatas media pelajaran memiliki pengaruh besar dalam pemerolehan informasi dan peningkatan pemahaman terhadap ilmu yang tengah dipelajari. Disisi lain media pembelajaran dapat digunakan untuk meningkatkan minat belajar siswa dan menghilangkan kebosanan dalam belajar. Dengan kata lain pembelajaran menggunakan media pembelajaran, terutama alat-alat teknologi baru yang disesuaikan dengan kemajuan zaman dapat meningkatkan efektifitas pembelajaran.

Jenis media pembelajaran sangat beragam. Berdasarkan ciri fisik media pembalajaran dikelompokkan menjadi empat, diantaranya : 
1. Media dua dimensi

Media dua dimensi adalah media pandang yang tampilannya dapat diamati ari satu arah pandang saja dengan dimensi panjang dan lebar (tanpa dimensi volume). Media dua dimensi berupa bidang datar, misalnya gambar, grafik, bagan, foto, kartu dan peta.

2. Media tiga dimensi

Media tiga dimensi merupakan media yang tampilannya dapat dinikmati dari erbagai arah. Media tiga dimensi memiliki dimensi panjang, lemar, tinggi dan tebal. Termasuk kategori ini anatara lain; benda model/tiruan, globe, bola, benda sesungguhnya, prototipe dan benda lain yang memiliki volume.

3. Media pandang diam

Media pandang diam ialah media pandang dengan alat proyeksi yng menampilkan gambar diam atau tidak bergerak.objek yang ditampilkan dalam layar bisa berupa foto, tulisan, gambar, dan lainnya.

4. Media pandang gerak

Media pandang gerak merupakan media yang menggunakan alat proyeksi yang dapat menampilkan gambar bergerak di layar, misal TV, VCD, film dan lain sebagainya. 
Menurut penggunaan media terkait alat Indera penyerap atau alat indera yang dirangsang, media diklasifikasikan menjadi tiga, yaitu :

1. Media Audio (Media sam'iyah)

Media audio ialah media penyampai pesan atau informasi dengan mengarahkan informasi ersebut kepada indra pendengar. Misalnya siaran radio,rekaman kaset, rekaman MP3, mendengarkan lagu, dan program di laboratorium bahasa. Media Audio biasa digunakan untuk melatih siswa menyimak dan membedakan bunyi-bunyi tertentu, mengucapkan dan menyimak pemahaman.

2. Media Visual (media Bashariyah)

Media yang mengarahkan informasi kepada indera penglihat. Berbagai jenis gambar, grafik, bagan, peragaan, tayangan film, dan sejenisnya termasuk media visual. Media visual dapat dikelompokkan lebih lanjut menjadi dua, yaitu berproyektor dan tanpa proyektor

3. Media Audio-Visual (Media Sam'iyah-Bashariyah)

Media Audio Visual merupakan media Pembelajaran yang digunakan guru untu menyampaikan materi agar diterima siswa melalui indera pendengar dan penglihat mereka secara terpadu. Media ini merupakan media yang paling lengkap. Yang termasuk dalam kategori media ini, antara lain televisi, VCD, Komputer dan Laboratorium. 
Pengelompokan media baik berdasarkan alat indera yang terlibat maupun berdasarkan ciri fisik berguna untuk memudahkan guru memilih maupun mengkolaborasikan media pembelajaran yang tepat sesuai tujuan dan kebutuhan pembelajaran tersebut. Selain itu semakin beragamnya jenis media pembelajaranan diharapkan tingkat efektifitas belajar meningkat sehingga mampu menciptakan suasana belajar yang aktif dan menyenangkan.

Gerlach dan Ely mengemukakan tiga karakteristik media berdasarkan petunjuk penggunaan media pembelajaran untuk mengantisipasi kondisi pembelajaran di mana guru tidak mampu atau kurang efektif dapat melakukannya. Ketiga karakteristik atau ciri media pembelajaran tersebut adalah:

1. Ciri fiksatif, yaitu yang menggambarkan kemampuan media untuk merekam, menyimpan, melestarikan, dan merekonstruksi suatu peristiwa atau obyek;

2. Ciri manipulative, yaitu kamampuan media untuk mentransformasi suatu obyek, kejadian atau proses dalam mengatasi masalah ruang dan waktu. Sebagai contoh, misalnya proses larva menjadi kepompong dan kemudian menjadi kupu-kupu dapat disajikan dengan waktu yang lebih singkat (atau dipercepat dengan teknik time-lapse recording). Atau sebaliknya, suatu kejadian/peristiwa dapat diperlambat penayangannya agar diperoleh urut-urutan yang jelas dari kejadian/peristiwa tersebut; 
3. Ciri distributif, yang menggambarkan kemampuan media mentransportasikan obyek atau kejadian melalui ruang, dan secara bersamaan kejadian itu disajikan kepada sejumlah besar siswa, di berbagai tempat, dengan stimulus pengalaman yang relatif sama mengenai kejadian tersebut.

Selain itu dalam penggunaan perlu memperhatikan halhal berikut :

1. Dasar teknologis, yakni penggunaan alat peraga berdasar kemajuan teknologi

2. Dasar psikologis, bahwa manusia memiliki tiga kemampuan, yaitu
a. Kognitisf (pengetahuan intelektual)
b. Afektif (sikap, perasaan dan nilai)
c. Psikomotor (keterampilan)

3. Dasar didaktis, penggunaan media hendaknya selaras dengan asas-asas didaktis, yaitu:
a. Peragaan
b. Minat
c. Motivasi
d. Kerja sendiri
e. Kerja kelompok
f. Lingkungan
g. Individual
h. Apersepsi
i. Korelasi 


\section{j. Ulangan}

Musik/lagu merupakan kekuatan dasar yang sangat efektif untuk menenangkan dan mendatangkan inspirasi bagi banyak orang. lagu menjadi salah satu solusi untuk merangsang pikran siswadapat menerima materi pembelajaran dengan baik. Sebagian besar orang didunia nampaknya mempunyai perasaan yang sama, karena pengaruh musik ada dimana-mana. Lagu menjadi alat yang efektif dan alamiah untuk membangun hubungan, mengembangkan dan memperluasnya. Lagu dapat digunakan sebagai "icebreaker" (pemecah suasana yang kaku) dan penguat hubungan.

Jauh sebelum anak-anak mampu mengucapkan katakata yang dapat dimengerti orangtua dapat memperkenalkan lagu untuk merangsang perkembangan otaknya. Karena kepekaan akan musik/nada dan unsur-unsurnya (ritme, pitch (tinggi rendahnya nada), timbre (warna suara) berkembang dengan kecepatan yang sama seperti berbicara. Musik/ lagu dapat menjadi alat bantu yg ampuh untuk mengembangkan kepekaan akan suara dan keterampilan berbahasa. Kecepatan anak menghapal sajak singkat, jingle-jingle iklan TV, dan lagulagu populer menunjukkan manfaat menggabungkan musik dengan bahasa verbal maupun nonverbal . Musik juga dapat membantu kita untuk rileks, mengendalikan diri, fokus, dan membersihkan pikiran kita. Musik dapat membantu kita semua-baik anak-anak maupun orang dewasa-untuk lebih 
mudah dan mempercepat menyimpan sejumlah besar informasi. Begitu kita memperoleh informasi tersebut, elemen musik seperti tempo, melodi dan ritme akan semakin memudahkan kita dikemudian hari untuk mengingat serta mengenali bukan hanya lagu serta liriknya, namun juga peristiwa dan perasaan yang berhubungan dengan musik tersebut.

Lagu baik digunakan sebagai media pembelajaan karena musik mampu menyeimbangkan otak kanan dan otak kiri, apalagi untuk materi-materi yang membutuhkan konsentrasi tinggi. lagu dapat pula meningkatkan kecerdasan, diantaranya:

1. Lagu dapat merangsang fungsi otak artinya musik memberikan rangsangan pertumbuhan fungsi fungsi pada otak. Fungsi ingatan untuk belajar,untuk berbahasa, untuk mendengar, dan berbicara, seta menganalisis intelektual dan fungsi kesadaran. Lagu $\mathrm{k}$ juga dapat merangsang pertumbuhan ingatan.

2. Merangsang otak secara fisik disini bukan berarti lagu yang memperbaiki kondisi fisik otak akan tetapi kondisi fisik otak yang lebih baik memungkinkan seseorang belajar musik.

3. Meningkatkan fungsi kognitif atinya musik memungkinkan untuk berfikir, mengingat, menganalisis, belajar dan secara umum melakukan aktifitas mental yang lebih tinggi. 
4. Merangsang proses asosiatif artinya lagu dapat menjadi perangsang yang membangkitkan siswa untuk mengingat kembali pengalaman emosional

5. Merangsang rekognitif ( mengenal kembali) artinya dengan lagu saraf indera pendengaran mengirim sinyal ke otak untuk mengenali kembali alunan musik tersebut. Jika siswa pernah mendengar lagu tersebut sebelumnya, maka siswa akan merespon terhadap sesuatu yang pernah dialaminya.

6. Lagu memperluas gudang ingatan artinya lagu mampu membangkitkn individu untuk memanggil kembali data lainnya karena adanya proses asosiatif. Lagu merupakan data yang juga berfungsi sebagai simulator untuk memanggil kembli ingatan lain

7. Merangsang perkembangan bahasa artinya lagu sering digunakan untuk membantu siswa agar lebih mampu mengembangkan penguasaan berbahasa.

8. Merangsang pikiran ritmis artinya lagu melatih koordinasi gerak dengan ritme, belajar dan memahami musik merupakan suatu proses belajar memahami irama

Apabila otak kiri bekerja seperti berpikir serius atau mempelajari ilmu baru, lagu dapat membangkitkan reaksi otak kanan yang intuitif dan kreatif sehingga masukannya dapat dipadukan dengan keseluruhan proses. Otak kanan cenderung mudah terganggu saat belajar, rapat dan kegiatan lainnya, yang menyebabkan mengapa orang senang melamun, atau 
memperhatikan hal lain. Memasang lagu adalah cara efektif untuk menyibukkan otak kanan ketika sedang berkonsentrasi menggunakan otak kiri67

Kekuatan dahsyat lagu yang dianggap biasa dapat sengaja digunakan untuk berbagai macam tujuan. Lagu dapat dijadikan sebagai motivator atau hadiah atas terselesaikannya tugas dan tanggung jawab. Lagu bisa menjadi sangat efektif di bidang akademis, dengan membantu pembentukan pola belajar, mengatasi kebosanan, dan menangkal kebisingan internal yang menggganggu (atau percakapan dalam pikiran). Lagu juga dapat membantu mengatur waktu dengan menciptakan kecepatan yang diinginkan. Dengan menstimulasi pikiran, mengaktifkan emosi, serta menyingkirkan keheningan yang kaku, musik mendorong terjadinya percakapan sosial, membantu dan mengembnangkan hubungan antar pribadi. Bahkan aktivitas mendengarkan musik saja telah terbukti mampu meningkatkan keterampilan mendengar secara umum, meningkatkan perhatian, dan mengungkapkan pandangan serta perasaan.

Penggunaan Media lagu dalam pembelajaran Bahasa Arab dapat membantu peserta didik mengatasi kesulitan dan kebosanan dalam belajar. Lirik dan ritme lagu membantu meningkatkan daya ingat, memperbaiki cara pengucapan serta dapat membantu memahami pesan lagu lebih dalam.

${ }^{67}$ Deporter dan hernacki, 2011 hal 74 
Sehimgga media lagu dapat digunakan sebagai media pembelajaran dalam mengajarkan komponen kebahasaan maupun pembelajaran kemahiran berbahasa.

Menyanyikan lagu berbahasa Arab dapat membantu mengembangkan kalam dengan intonasi yang alami. Karena pada dasarnya pemerolehan bahasa (iktisab al lughah) dimulai melalui pendengaran (istima').Dapat dikatakan bahwa pembelajaran kalam dan Istima' dapat dilakukan seiring sejalan baik menggunakan lagu gubahan maupun lagu yang diciptakan sesuai tema pembelajaran. Pembelajaran dapat dilakukan dengan memperdengarkan lagu kepada peserta didik hingga hafal kemudian peserta didik diajak menyanyikan lagu tersebut. Kesalahan kesalahan intonasi maupun pelafalan dapat dillakukan sembari peserta didik melafalkan lagu yang tengah dipelajari.

Pembelajaran Kemahiran Qira'ah melalui media lagu dapat diterapkan dengan memberikan naskah lagu kemudian siswa diminta menyanyikan. Sedangkan kemahiran menulis dapat dilakukan dengan membagikan naskah lagu dengan kosakata yang terbatas, dimana peserta didik menuliskan katakata yang tidak ada ataupun memberikan tugas kepada peserta didik untuk menceritakan kembali lirik lagu tersebut sesuai pemahaman. 


\section{Penutup}

Media pembelajaran sanga penting dalam kegiatan pembelajaran bahasa Arab. Media mampu meningkatkan efektivitas pembelajaran bahasa Arab yang dinilai cukup rumit bagi peserta didik. Dalam pembelajaran bunyi bahasa Arab, media lagu dapat digunakan untuk mengenalkan bunyi bahasaa Arab dari tingkat dasar hingga tingkat lanjut. Lagu yang digunakan daalam pembelajaran ashwat dapat didesain sedemikian rupa menyesuaikan kondisi peserta didik. Pengenalan ashwat tingkat dasar dapat digunakan lagu-lagu yang mengenalkan huruf hijaiyah dengan pelafalan yang jelas sesuai makhorijul huruf. Pengenalan ashwat tingkat lanjut dapat menggunakan lagu dalam bentuk mufrodat maupun dalam bentuk jumlah mufidah.

Pembelajaran kemahiran berbahasa dan komponenkomponen berbahasa, untuk mengurangi kejenuhan siswa sehingga mampu mampu menyerap pembelajaran, media lagu dapat disematkan dalam setiap kegiatan pembelajaran. Mendengarka dan menyanyikan lagu dapat dijadikan salah satumedia pembelajaran istima' dan kalam. Pembelajaran qira'ah dapat digunakan teks lagu untk dinyanyikan bersama. Pembelajaran kitabah dapat dilakukan dengan menuliskan intisari lagu maupun menuliskan apa yag didengar 


\section{DAFTAR PUSTAKA}

Arif S. sardiman, Media pendidikan : pengertian, pengembangan, dan pemanfaatannya, (Jakarta: Rajawali, 1990)

Azhzar Arsyad, Media Pembelajaran( jakarta; Raja Grafindo, 2007)

Abdul Hamid, dkk, Pembelajaran Bahasa Arab: Metode, Strategi, Materi dan Media, (Malang:UIN Malang Press, 2010)

Deporter dan hernacki, Quantum Learning, (Jakarta: Kaifa, 2011)

Djohan, Psikologi Musik, (Yogyakarta: Buku Baik, 2005)

http://blog.elearning.unesa.ac.id/fatma-amelia/terapi-musikbagi-anak-tuna-rungu disunting selasa, 6 maret 2018

Imam Asrori, Media Pembelajaran, (Malang:UIN Malang Press, 2010)

Orthiz, John M., Nurturing Your hild with Music, (Jakata: Gramedia, 2002)

Rosyidi, abdul Wahab, Media pembelajaran Bahasa Arab, (Malang : UIN Malang Press, 2009) 